\title{
Protein synthesis and degradation in non-cultured and in-vitro cultured rabbit blastocysts
}

\author{
Th. Jung* \\ Abteilung Anatomie und Reproduktionsbiologie, Medizinische Fakultät, RWTH Aachen, \\ D-5100 Aachen, FRG
}

\begin{abstract}
Summary. In 'pulse-chase' experiments synthesis and half-lives of leucine-labelled proteins were determined in rabbit blastocysts. Embryos were either non-cultured controls or were cultured for $24 \mathrm{~h}$ or $48 \mathrm{~h}$ in Ham's F-10 medium supplemented with homologous serum or uterine flushings. In control blastocysts protein synthesis increased by a factor of 10 between Day 4 and Day 5 . Half-lives of newly synthesized proteins were $32 \mathrm{~h}$ in Day-4 and $99 \mathrm{~h}$ in Day- 5 control blastocysts. In-vitro culture of Day-4 blastocysts led to dramatically shortened half-lives, amounting to $6-10 \mathrm{~h}$. Blastocysts developing in uterine flushing-supplemented media differed significantly from those cultured in serum-supplemented media. Protein synthesis was enhanced and protein degradation was normal for culture times up to $24 \mathrm{~h}$. These results demonstrate (1) that half-lives of proteins in rabbit blastocysts increase with advancing embryonic age, and (2) that a characteristic feature of the altered metabolism of cultured blastocysts is a dramatically accelerated protein degradation, which (3) can be prevented for some time by supplementation of the culture medium with uterine secretions.
\end{abstract}

Keywords: rabbit; blastocysts; protein synthesis; protein degradation; in-vitro culture; uterine secretions

\section{Introduction}

Protein synthesis in rabbit embryos has been studied at various developmental stages in vivo as well as in vitro (Manes \& Daniel, 1969; Klinger et al., 1971; Karp et al., 1974; Lambert \& Hamner, 1978; Matheson \& Schultz, 1980; Jung et al., 1987; Jung \& Fischer, 1988). However, less information is available on protein degradation by preimplantation embryos (Epstein \& Smith, 1974; Brinster et al., 1976, 1979; Merz et al., 1981; Wiebold \& Anderson, 1985).

The present study was performed to investigate protein synthesis and degradation in cultured and non-cultured rabbit blastocysts.

\section{Materials and Methods}

Embryos and in-vitro culture. Rabbit blastocysts were obtained from superovulated cross-bred females 4 or 5 days after mating (Jung et al., 1987; Fischer \& Meuser-Odenkirchen, 1988). Uteri were flushed with medium BSM II containing $0 \cdot 1 \%$ BSA (Maurer, 1978). Embryos were washed free of genital tract fluid, examined under a stereomicroscope, pooled, and allocated randomly to the various experimental groups. In-vitro culture was performed in $1 \mathrm{ml}$ Ham's F-10 medium (Ham, 1963) supplemented with $10 \%$ (v/v) heat-inactivated blood serum from Day-4 pregnant females or with uterine flushings derived from Day-4 pseudopregnant does (Jung et al., 1987). Uterine flushings were obtained by instillation of $3 \mathrm{ml}$ protein-free Ham's F-10 medium into excised, double-ligated uteri.

*Present address: Institut für Medizinische Strahlenbiologie, Universitätsklinikum Essen, Hufelandstraße 55, D-4300 Essen 1, FRG. 
After 30-45 min storage at $37^{\circ} \mathrm{C}$ the medium was recovered and the cellular components were removed by centrifugation. The protein concentrations amounted to $7-8 \mathrm{mg} / \mathrm{ml}$ in serum-supplemented media and ranged from 2.5 to $5.0 \mathrm{mg} / \mathrm{ml}$ in media supplemented with uterine secretions.

Amino acid incorporation. Blastocysts were pulse labelled for $2 \mathrm{~h}$ in $1 \mathrm{ml}$ Ham's F-10 medium containing L- $\left[4,5-{ }^{3} \mathrm{H}\right]$ leucine (sp. act. $1.91 \mathrm{TBq} / \mathrm{mmol}$; Amersham Buchler, Braunschweig, FRG) at $1.85 \mathrm{MBq} / \mathrm{ml}$, then rinsed 5 times in medium BSM II containing 0.1\% BSA and randomly allocated to 3 groups. Embryos in Groups 2 and 3 were chase cultured for $2.5 \mathrm{~h}$ or $5 \mathrm{~h}$, respectively, in Ham's F-10 medium supplemented with $10 \%$ (v/v) rabbit serum and enriched with unlabelled leucine (final concentration: $100 \mathrm{~mm}$ ). The chase medium contained a 1000 -fold greater concentration of leucine than the pulse medium in order to prevent the re-incorporation of the labelled amino acid. After the chase periods or immediately after pulsing (Group 1) the embryos were rinsed 5 times in PBS (phosphatebuffered saline, Dulbecco \& Vogt, 1954) and processed individually for scintillation counting. Processing involved lysis in a buffer ( $1 \%$ SDS, $0.05 \%$ DTT and $8 \mathrm{M}$-urea in $\mathrm{H}_{2} \mathrm{O}$ ), freezing, precipitation of embryonic proteins with TCA, centrifugation, dissolution of the pellet in a tissue homogenizer, and liquid scintillation counting (for further methodological details see Jung et al., 1987).

Statistical analysis. Differences were assessed by the Kruskal-Wallis non-parametric test with multiple comparisons (synthesis studies) or by analysis of variance (degradation studies). Pair comparisons were made by the two sided Mann-Whitney-Wilcoxon test or by Duncan's multiple $t$ test. Least squares regression analysis was used to analyse the logarithmically transformed recovery rates after the chase periods of pulse incorporated $\left[{ }^{3} \mathrm{H}\right]$ leucine (pulse period $=100 \%$ recovery rate). The mean half-life $\left(t_{1}\right)$ of labelled proteins was calculated from the equation of regression (Sachs, 1984).

\section{Results}

\section{Control blastocysts}

Embryonic protein synthesis increased by a factor of 10 from Day 4 to Day 5 (Table 1: see incorporation data after pulse period). Half-lives of the labelled proteins amounted to $32 \mathrm{~h}$ and $99 \mathrm{~h}$ in Day-4 and Day-5 blastocysts, respectively (Table 1). Because of the short chase periods in comparison to the calculated half-lives, the coefficients of regression for protein degradation were not statistically significantly different, indicating only the tendency towards longer half-lives with advancing age (Table 3 ).

Table 1. Protein synthesis and degradation in non-cultured Day-4 and Day-5 rabbit blastocysts

\begin{tabular}{|c|c|c|c|c|c|}
\hline \multirow{3}{*}{$\begin{array}{l}\text { Embryonic } \\
\text { age } \\
\text { (Day p.c.) }\end{array}$} & \multirow{2}{*}{$\begin{array}{l}\text { Pulse period } \\
\quad(2 \mathrm{~h})\end{array}$} & \multicolumn{2}{|c|}{ Chase period } & \multirow{3}{*}{$\begin{array}{c}\text { Coefficient of } \\
\text { regression* } \\
(1 / \mathrm{h})\end{array}$} & \multirow{3}{*}{$\begin{array}{l}\text { Half- } \\
\text { life } \\
\text { (h) }\end{array}$} \\
\hline & & $2 \cdot 5 \mathrm{~h}$ & $5 \mathrm{~h}$ & & \\
\hline & \multicolumn{3}{|c|}{ (pmol incorporated leucine per blastocyst) } & & \\
\hline 4 & $\begin{array}{c}6 \cdot 6(0.4) \\
100 \%(6 \%) \dagger \\
\mathrm{N}=9 ; n=61\end{array}$ & $\begin{array}{c}6 \cdot 0(0 \cdot 4) \\
92 \%(7 \%) \\
\mathrm{N}=3 ; n=23\end{array}$ & $\begin{array}{c}5.9(0.5) \\
90 \%(8 \%) \\
\mathrm{N}=3 ; n=25\end{array}$ & $-0.021(0.010)$ & 32 \\
\hline 5 & $\begin{array}{c}65 \cdot 6(3 \cdot 9) \\
100 \%(6 \%) \\
\mathrm{N}=7 ; n=91\end{array}$ & $\begin{array}{c}61 \cdot 3(3 \cdot 9) \\
93 \%(6 \%) \\
\mathrm{N}=3 ; n=58\end{array}$ & $\begin{array}{c}64 \cdot 0(6 \cdot 0) \\
98 \%(9 \%) \\
\mathrm{N}=3 ; n=38\end{array}$ & $-0.007(0.008)$ & 99 \\
\hline
\end{tabular}

Values given are weighted means (s.e.m.) for $\mathrm{N}=$ number of independent experiments and $n=$ number of blastocysts used.

*Calculated after logarithmic transformation of the incorporation data.

$\dagger \%$ Recovery of incorporated leucine.

\section{Cultured blastocysts}

After $24 \mathrm{~h}$ in culture leucine incorporation was approximately doubled compared with Day-4 controls $(P<0.001)$, irrespective of the medium supplement involved (Table $2, P>0.05$ ). 
Blastocysts cultured for $24 \mathrm{~h}$ in serum-supplemented Ham's F-10 medium showed a statistically significantly enhanced protein degradation as demonstrated by reduced recovery rates $(P<0.01)$ and a mean half-life of labelled proteins of $7 \mathrm{~h}(P<0.001$, Table 2$)$. Protein degradation in blastocysts grown in media supplemented with uterine flushings for up to $24 \mathrm{~h}$ was comparable to that of Day-4 control blastocysts $(P>0 \cdot 05$, Table 2$)$.

Table 2. Protein synthesis and degradation in in-vitro cultured Day-4 rabbit blastocysts

\begin{tabular}{|c|c|c|c|c|c|}
\hline \multirow{3}{*}{$\begin{array}{l}\text { Ham's F-I0 } \\
\text { medium } \\
\text { supplemented } \\
\text { with: }\end{array}$} & \multirow{2}{*}{$\begin{array}{l}\text { Pulse period } \\
\qquad(2 \mathrm{~h})\end{array}$} & \multicolumn{2}{|c|}{ Chase period } & \multirow{3}{*}{$\begin{array}{c}\text { Coefficient of } \\
\text { regression* } \\
(1 / \mathrm{h})\end{array}$} & \multirow{3}{*}{$\begin{array}{l}\text { Half- } \\
\text { life } \\
\text { (h) }\end{array}$} \\
\hline & & $2 \cdot 5 \mathrm{~h}$ & $5 \mathrm{~h}$ & & \\
\hline & \multicolumn{3}{|c|}{ (pmol incorporated leucine per blastocyst) } & & \\
\hline $\begin{array}{l}24 \mathrm{~h} \text { serum } \\
(24 \mathrm{~S})\end{array}$ & $\begin{array}{c}13 \cdot 3(1 \cdot 2) \\
100 \%(9 \%) \dagger \\
\mathrm{N}=7 ; n=46\end{array}$ & $\begin{array}{c}11 \cdot 3(1 \cdot 4) \\
85 \%(11 \%) \\
\mathrm{N}=3 ; n=24\end{array}$ & $\begin{array}{c}7 \cdot 7(0 \cdot 4) \\
58 \%(3 \%) \\
\mathrm{N}=3 ; n=25\end{array}$ & $-0.107(0.012)$ & 7 \\
\hline $\begin{array}{l}24 \mathrm{~h} \text { uterine flushing } \\
(24 \mathrm{U})\end{array}$ & $\begin{array}{c}13.0(0 \cdot 9) \\
100 \%(7 \%) \\
N=4 ; n=36\end{array}$ & $\begin{array}{c}12 \cdot 4(1 \cdot 1) \\
95 \%(8 \%) \\
\mathrm{N}=3 ; n=19\end{array}$ & $\begin{array}{c}11 \cdot 5(1 \cdot 2) \\
88 \%(9 \%) \\
\mathrm{N}=3 ; n=19\end{array}$ & $-0.027(0.016)$ & 26 \\
\hline $\begin{array}{l}48 \mathrm{~h} \text { serum } \\
(48 \mathrm{~S})\end{array}$ & $\begin{array}{c}19 \cdot 8(1 \cdot 6) \\
100 \%(8 \%) \\
N=6 ; n=41\end{array}$ & $\begin{array}{c}12 \cdot 8(1.2) \\
65 \%(8 \%) \\
\mathrm{N}=4 ; n=28\end{array}$ & $\begin{array}{c}12 \cdot 4(0 \cdot 9) \\
63 \%(5 \%) \\
\mathrm{N}=3 ; n=22\end{array}$ & $-0.100(0.014)$ & 6 \\
\hline $\begin{array}{l}48 \mathrm{~h} \text { uterine flushing } \\
(48 \mathrm{U})\end{array}$ & $\begin{array}{c}28 \cdot 7(2 \cdot 5) \\
100 \%(9 \%) \\
\mathrm{N}=5 ; n=42\end{array}$ & $\begin{array}{c}23 \cdot 5(2 \cdot 7) \\
85 \%(9 \%) \\
\mathrm{N}=3 ; n=19\end{array}$ & $\begin{array}{c}17 \cdot 1(1 \cdot 5) \\
59 \%(5 \%) \\
\mathrm{N}=3 ; n=21\end{array}$ & $-0 \cdot 102(0 \cdot 019)$ & 7 \\
\hline $\begin{array}{l}24 \mathrm{~h} \text { serum } \\
+24 \mathrm{~h} \text { uterine flushing } \\
(24 \mathrm{~S}+24 \mathrm{U})\end{array}$ & $\begin{array}{c}32 \cdot 0(1 \cdot 6) \\
100 \%(5 \%) \\
\mathrm{N}=4 ; n=35\end{array}$ & $\begin{array}{c}21 \cdot 1(1 \cdot 7) \\
66 \%(5 \%) \\
\mathrm{N}=2 ; n=20\end{array}$ & $\begin{array}{c}18 \cdot 2(1 \cdot 3) \\
57 \%(4 \%) \\
\mathrm{N}=3 ; n=31\end{array}$ & $-0 \cdot 113(0.014)$ & 6 \\
\hline $\begin{array}{l}24 \mathrm{~h} \text { uterine flushing } \\
+24 \mathrm{~h} \text { serum } \\
(24 \mathrm{U}+24 \mathrm{~S})\end{array}$ & $\begin{array}{c}30 \cdot 9(2 \cdot 2) \\
100 \%(7 \%) \\
\mathrm{N}=2 ; n=23\end{array}$ & $\begin{array}{c}23 \cdot 0(2 \cdot 1) \\
74 \%(7 \%) \\
\mathrm{N}=2 ; n=22\end{array}$ & $\begin{array}{c}21 \cdot 1(2 \cdot 3) \\
68 \%(8 \%) \\
\mathrm{N}=2 ; n=22\end{array}$ & $-0.076(0.019)$ & 9 \\
\hline $\begin{array}{l}24 \mathrm{~h} \text { uterine flushing } \\
+24 \mathrm{~h} \text { uterine flushing } \\
(24 \mathrm{U}+24 \mathrm{U})\end{array}$ & $\begin{array}{c}29 \cdot 7(2 \cdot 5) \\
100 \%(8 \%) \\
\mathrm{N}=2 ; n=25\end{array}$ & $\begin{array}{c}22 \cdot 4(2 \cdot 7) \\
76 \%(9 \%) \\
\mathrm{N}=2 ; n=24\end{array}$ & $\begin{array}{c}18 \cdot 5(2 \cdot 0) \\
62 \%(7 \%) \\
\mathrm{N}=2 ; n=24\end{array}$ & $-0.062(0.017)$ & 10 \\
\hline
\end{tabular}

Values given are weighted means (s.e.m.) for $\mathrm{N}=$ number of independent experiments and $n=$ number of blastocysts used.

${ }^{*}$ Calculated after logarithmic transformation of the incorporation data.

$\uparrow \%$ Recovery of incorporated leucine.

Table 3. Coefficients of regression for protein degradation

\begin{tabular}{lllllllll}
\hline $\begin{array}{l}\text { Experimental } \\
\text { groups }\end{array}$ & Day 4 & Day 5 & $24 \mathrm{~S}$ & $24 \mathrm{U}$ & $48 \mathrm{~S}$ & $48 \mathrm{U}$ & $\begin{array}{c}24 \mathrm{~S} \\
+24 \mathrm{U}\end{array}$ & $\begin{array}{c}24 \mathrm{U} \\
+24 \mathrm{~S}\end{array}$ \\
\hline $\begin{array}{l}\text { Day } 5 \\
24 \mathrm{~S}\end{array}$ & n.s. & & & & & & \\
$24 \mathrm{U}$ & n.s. & n.s. & $* * *$ & & & & \\
$48 \mathrm{~S}$ & $* * *$ & $* * *$ & n.s. & $* * *$ & & & \\
$48 \mathrm{U}$ & $* * *$ & $* * *$ & n.s. & $* * *$ & n.s. & & \\
$24 \mathrm{~S}+24 \mathrm{U}$ & $* * *$ & $* * *$ & n.s. & $* * *$ & n.s. & n.s. & & \\
$24 \mathrm{U}+24 \mathrm{~S}$ & $* *$ & $* * *$ & n.s. & $*$ & n.s. & n.s. & $*$ & \\
$24 \mathrm{U}+24 \mathrm{U}$ & $*$ & $* *$ & $*$ & $*$ & $*$ & $*$ & $*$ & n.s. \\
\hline
\end{tabular}

†See Tables 1 and 2.

${ }^{*} P<0.05 ;{ }^{* *} P<0.01 ;{ }^{* *} P<=0.001$; n.s. $=P>0.05$. 
After $48 \mathrm{~h}$ in vitro, blastocysts in serum-supplemented Ham's F-10 medium incorporated leucine at only a slightly higher level than after a 24 -h culture period (Table $2, P<0.01$ ), while supplementation with uterine flushings resulted in a marked increase (Table $2, P<0.001$ ). This stimulating effect of uterine secretions after $48 \mathrm{~h}$ in vitro was independent from duration $(24 \mathrm{~h}$ or $48 \mathrm{~h}, P>0.05$ ) and time (1st or 2 nd 24 -h period, $P>0.05$ ) of supplementation, or of renewal of the medium after $24 \mathrm{~h}(P>0.05$, Table 2$)$.

Culture for $48 \mathrm{~h}$ in serum- or uterine flushing-supplemented media resulted in a marked enhancement of protein degradation, as indicated by half-lives of $6-10 \mathrm{~h}$ (Tables 2 and 3 ). Supplementation with serum during the first $24 \mathrm{~h}$ of the 2-day culture led to a more pronounced protein breakdown $\left(t_{\frac{1}{2}}=\sim 6 \mathrm{~h}\right.$, Table 2$)$ than did supplementation with uterine secretions $\left(t_{\frac{1}{2}}=\right.$ $7-10 \mathrm{~h}$, Table 2 ). The recovery rates after the $2 \cdot 5$-h chase period were clearly reduced in blastocysts grown in serum-supplemented medium during the first $24 \mathrm{~h}$ (Table $2, P<0.05$ ), indicating a larger proportion of proteins with short half-lives in these embryos.

\section{Discussion}

There is little information available concerning protein degradation in preimplantation embryos. Half-lives of newly synthesized proteins in ovulated unfertilized oocytes and zygotes of the mouse are approximately 17-18 h (Merz et al., 1981). For cleavage-stage mouse embryos slightly different results are reported, mainly caused by methodological differences such as the durations of the chase periods. Brinster et al. (1976) and Wiebold \& Anderson (1985) calculated half-lives of 18-20 h (chase periods of up to $24 \mathrm{~h}$ ), while Merz et al. (1981) found 12-13 h (chase periods of up to $5 \mathrm{~h}$ ). Half-lives of 11-14 h are reported for mouse morulae and blastocysts (Brinster et al., 1976, 1979; Merz et al., 1981; Wiebold \& Anderson, 1985).

In comparison to mouse embryos, proteins synthesized by rabbit blastocysts clearly have longer half-lives, which differ considerably between blastocysts of different ages (29-99 h; Table 1). This finding is in good agreement with changes in the protein content during the preimplantation developmnent in these species. In the mouse the protein content diminishes from the oocyte up to the morula stage to increase with blastocyst formation (Brinster, 1967; Schiffner \& Spielmann, 1976). In the rabbit the protein content remains constant up to the morula stage and increases afterwards significantly faster than in the mouse (Brinster, 1971), probably correlated to the higher cell proliferation.

It is well known that, compared with non-cultured controls, cultured embryos show significant changes in metabolism such as reduced metabolic activity (Anderson \& Foote, 1975a, b; Sellens $e t$ al., 1981; Edirisinghe et al., 1984), retarded cell proliferation (Streffer et al., 1980; Fischer, 1987, 1988 ) and lower cell number (Anderson \& Foote, 1975a; Kane, 1983, 1985). In a previous study we were able to demonstrate that the reduced amino acid incorporation of cultured rabbit blastocysts was dependent on length of the in-vitro culture and on the medium supplement involved (Jung $e t$ $a l ., 1987)$. The present findings demonstrate that in-vitro culture not only changes protein synthesis but also enhances protein degradation.

In cultured Day-3 and Day-4 rabbit embryos there is an increase in secondary lysosomes and in the number of degenerated cells (Fischer, 1988; Hegele-Hartung et al., 1988). Similar morphological differences have been described for mouse blastocysts cultured in vitro (McReynolds \& Hadek, 1972).

Under physiological conditions lysosomes play only a minor non-selective role in the turnover of cellular proteins, but the basal rates of proteolysis increase when mammalian cells in vitro are deprived of growth factors or essential nutrients. In this situation most of the enhanced proteolysis results from autophagy. Portions of the cytoplasm are randomly encapsulated in membrane vesicles that subsequently fuse with lysosomes (Waterlow et al., 1978; Amenta \& Brocher, 1981; Rechsteiner, 1987). The observed types of cell death in cultured Day-4 rabbit blastocysts are 
necrosis and, mainly, apoptosis (Fischer, 1988). Apoptotic bodies are either extruded into an adjacent lumen (in embryos: blastocyst cavity and perivitelline space) or undergo phagocytosis by nearby cells (Wyllie, 1981; Fischer, 1988). In-vitro culture is therefore characterized not only by a developmental retardation, but also by clearly enhanced breakdown reactions, shown by morphological and protein-degradation studies.

DNA, RNA and protein synthesis function on significantly higher levels when cultured rabbit blastocysts have access to uterine flushing proteins or secretions in vitro (Gulyas et al., 1969; El-Banna \& Daniel, 1972a, b; Fischer, 1987, 1988; Jung et al., 1987). In our previous and in the present study (Table 2) we were able to demonstrate that uterine secretions exert their favourable effects in a time-dependent fashion, i.e. on embryonic protein synthesis not before $48 \mathrm{~h}$ in vitro. In addition, stimulation of amino acid incorporation was generally found in experimental groups having access to uterine flushings for at least one 24-h period within 2 days of in-vitro culture. The beneficial effects of uterine secretions on blastocyst development in vitro become particularly clear from the protein-degradation studies. Up to $24 \mathrm{~h}$ in vitro, uterine secretions prevented enhanced proteolytic activity in cultured blastocysts (Table 2). Normal in-vitro development of rabbit embryos therefore seems at present to be limited to short culture times and to supplementation of the culture medium with uterine flushing. Thereafter and under suboptimal conditions embryonic development in vitro should not be characterized as retarded but as hindered. Apart from nutritional effects this suggests the presence of some uterine factors, which support embryo development and which are able to act differently on embryonic protein synthesis and degradation.

Embryo development in vitro cannot be evaluated by the morphological development of the blastocyst but rather by the maintenance of its subsequent developmental viability (Gandolfi $\&$ Moor, 1987). In the rabbit the rate of blastocyst formation in vitro is very high (Kane, 1975; Maurer \& Beier, 1976), but the viability of blastocysts grown in vitro is limited (Maurer, 1978; Beier et al., 1983; for review see Fischer, 1988). This failure in developmental capacity may reflect the decisive requirements for subtle uterine factors missing in vitro analogous to those known to influence embryonic development in sheep (Wilmut \& Sales, 1981; Gandolfi \& Moor, 1987).

I thank Susanne Echterhagen and Sabina Hennes for valuable assistance; and Dr B. Fischer and Prof. H. M. Beier for critical reading of the manuscript and for stimulating discussion throughout the work. This study was supported by two grants from the Deutsche Forschungsgemeinschaft, Bonn-Bad Godesberg, within the research programme on "Biologie und Klinik der Reproduktion" (Fi 306/1-2, Be 524/7-8).

\section{References}

Amenta, J.S. \& Brocher, S.C. (1981) Mechanisms of protein turnover in cultured cells. Life Sci. 28, $1195-1208$.

Anderson, G.B. \& Foote, R.H. (1975a) Development of rabbit embryos in vitro and in vivo following storage of the two-cell stage at $10^{\circ} \mathrm{C}$. J. Reprod. Fert. 45, 151-153.

Anderson, G.B. \& Foote, R.H. (1975b) Effects of low temperature upon subsequent nucleic acid and protein synthesis of rabbit embryos. Expl Cell Res. 90, $73-78$.

Beier, H.M., Mootz, U., Fischer, B. \& Stroebele-Mueller, R. (1983) Growth and differentiation of rabbit blastocysts in defined culture media. In Fertilization of the Human Egg In Vitro, pp. 371-386. Eds H. M. Beier \& H. R. Lindner. Springer-Verlag, Berlin.

Brinster, R.L. (1967) Protein content of the mouse embryo during the first five days of development. $J$. Reprod. Fert. 13, 413-420.

Brinster, R.L. (1971) Activity of 6-phosphogluconate dehydrogenase in the preimplantation mouse and rabbit embryo. Experientia 27, 371-372.

Brinster, R.L., Wiebold, J.L. \& Brunner, S. (1976) Protein metabolism in preimplanted mouse ova. Devl Biol. 51, 215-224.

Brinster, R.L., Brunner, S., Joseph, X. \& Levey, I.L. (1979) Protein degradation in the mouse blastocyst. J. biol. Chem. 254, 1927-1931.

Dulbecco, R. \& Vogt, M. (1954) Plaque formation and isolation of pure lines with poliomyelitis viruses. $J$. exp. Med. 99, 167-182.

Edirisinghe, W.R., Wales, R.G. \& Pike, I.L. (1984) Degradation of biochemical pools labelled with $\left[{ }^{14} \mathrm{C}\right]$ glucose during culture of 8 -cell and morula- 
early blastocyst-stage mouse embryos in vitro and in vivo. J. Reprod. Fert. 72, 59-65.

El-Banna, A.A. \& Daniel, J.C., Jr (1972a) Stimulation of rabbit blastocysts in vitro by progesterone and uterine proteins in combination. Fert. Steril. 23, 101-104.

El-Banna, A.A. \& Daniel, J.C., Jr (1972b) The effect of protein fractions from rabbit uterine fluids on embryo growth and uptake of nucleic acid and protein precursors. Fert. Steril. 23, 105-114.

Epstein, C.J. \& Smith, S.A. (1974) Electrophoretic analysis of proteins synthesized by preimplantation mouse embryos. Devl Biol. 40, 233-244.

Fischer, B. (1987) Developmental retardation in cultured preimplantation rabbit embryos. J. Reprod. Fert. 79, 115-123.

Fischer, B. (1988) Embryonalentwicklung in vitro und in vivo. Charakterisierung entwicklungsspezifischer Strukturen und Lebensäußerungen von Präimplantationsembryonen in vitro und in vivo. Enke Verlag, Stuttgart.

Fischer, B. \& Meuser-Odenkirchen, G. (1988) A 2 year follow-up of effects of biotechniques on reproduction in the domestic rabbit, Oryctolagus cuniculus. $L a b$. Anim. 22, 5-15.

Gandolfi, F. \& Moor, R.M. (1987) Stimulation of embryonic development in the sheep by co-culture with oviduct epithelial cells. J. Reprod. Fert. 81, 23-28.

Gulyas, B.J., Daniel, J.C., Jr \& Krishnan, R.S. (1969) Incorporation of labelled nucelosides in vitro by rabbit and mink blastocysts in the presence of blastokinin or serum. J. Reprod. Fert. 20, 255-262.

Ham, R.G. (1963) An improved nutrient solution for diploid Chinese hamster and human cell lines. Expl Cell Res. 29, 515-526.

Hegele-Hartung, C., Fischer, B. \& Beier, H.M. (1988) Development of preimplantation rabbit embryos after in-vitro culture and embryo transfer: an electron-microscopic study. Anat. Rec. 220, 31-42.

Jung, T. \& Fischer, B. (1988) Correlation between blastocyst diameter and DNA or protein synthetic activity in rabbit blastocysts. Biol. Reprod. 39, 1111-1116.

Jung, T., Fischer, B. \& Beier, H.M. (1987) Quantitative aspects of protein synthesis in non-cultured and cultured rabbit blastocysts. Hum. Reprod. 2, 23- 27.

Kane, M.T. (1975) Bicarbonate requirements for culture of one-cell rabbit ova to blastocysts. Biol. Reprod. 12, $552-555$.

Kane, M.T. (1983) Variability in different lots of commercial bovine serum albumin affects cell multiplication and hatching of rabbit blastocysts in culture. J. Reprod. Fert. 69, 555-558.

Kane, M.T. (1985) A low molecular weight extract of bovine serum albumin stimulates rabbit blastocyst cell division and expansion in vitro. J. Reprod. Fert. 73, 147-150.

Karp, G.C., Manes, C. \& Hahn, W.E. (1974) Ribosome production and protein synthesis in the preimplantation rabbit embryo. Differentiation 2, 65-73.
Klinger, H.P., Kosseff, A.L. \& Plotnik, F. (1971) Sexchromatin formation and RNA and protein synthesis during preimplantation development of the rabbit. In Advances in the Biosciences, Vol. 6, pp. 207-224. Ed. G. Raspé. Pergamon Press-Vieweg Verlag, Edinburgh.

Lambert, R.D. \& Hamner, C.E. (1978) RNA and protein synthesis in preimplantation rabbit embryos. Anim. Reprod. Sci. 1, 61-68.

Manes, C. \& Daniel, J.C., Jr (1969) Quantitative and qualitative aspects of protein synthesis in the preimplantation rabbit embryo. Expl Cell Res. 55, 261-268.

Matheson, R.C. \& Schultz, G.A. (1980) Histone synthesis in preimplantation rabbit embryos. J. exp. Zool. 213, 337-349.

Maurer, R.R. (1978) Advances in rabbit embryo culture. In Methods in Mammalian Reproduction, pp. 259-272. Ed J. C. Daniel, Jr. Academic Press, New York.

Maurer, R.R. \& Beier, H.M. (1976) Uterine proteins and development in vitro of rabbit preimplantation embryos. J. Reprod. Fert. 48, 33-42.

McReynolds, H.D. \& Hadek, R. (1972) A comparison of the fine structure of late mouse blastocysts developed in vivo and in vitro. J. exp. Zool. 182, 95-118.

Merz, E.A., Brinster, R.L., Brunner, S. \& Chen, H.Y. (1981) Protein degradation during preimplantation development of the mouse. J. Reprod. Fert. 61, 415-418.

Rechsteiner, M. (1987) Ubiquitin-mediated pathways for intracellular proteolysis. Ann. Rev. Cell Biol. 3, 1-30.

Sachs, L. (1984) Applied Statistics. A Handbook of Techniques. Springer-Verlag, Berlin.

Schiffner, J. \& Spielmann, H. (1976) Fluorometric assay of the protein content of mouse and rat embryos during preimplantation development. $J$. Reprod. Feri. 47, 145-147.

Sellens, M.H., Stein, S. \& Sherman, M.T. (1981) Protein and free amino acid content in preimplantation mouse embryos and in blastocysts under various culture conditions. J. Reprod. Fert. 61, 307-315.

Streffer, C., van Beuningen, D., Molls, M., Zamboglou, N. \& Schulz, S. (1980) Kinetics of cell proliferation in the preimplanted mouse embryo in vivo and in vitro. Cell Tissue Kinet. 13, 135-143.

Waterlow, J.C., Garlick, P.J. \& Millward, D.J. (1978) Protein Turnover in Mammalian Tissues and in the Whole Body. North-Holland Publ. Corp., Amsterdam.

Wiebold, J.L. \& Anderson, G.B. (1985) Lethality of a tritiated amino acid in early mouse embryos. $J$. Embryol. exp. Morph. 88, 209-217.

Wilmut, I. \& Sales, D.I. (1981) Effect of an asynchronious environment on embryonic development in sheep. J. Reprod. Fert. 61, 179-184.

Wyllie, A.H. (1981) Cell death: a new classification separating apoptosis from necrosis. In Cell Death in Biology and Pathology, pp. 9-34. Eds I. D. Bowen \& R. A. Lockskin. Chapman \& Hall, London.

Received 21 September 1988 